\title{
Expression levels of the $\alpha 7$ nicotinic acetylcholine receptor in the brains of patients with Alzheimer's disease and their effect on synaptic proteins in SH-SY5Y cells
}

\author{
JIA-MOU REN ${ }^{1-3}$, SHU-LI ZHANG ${ }^{1,2,4}$, XIAO-LING WANG ${ }^{1,2}$, ZHI-ZHONG GUAN $^{1,2,5}$ and XIAO-LAN QI ${ }^{1,2}$ \\ ${ }^{1}$ Key Laboratory of Endemic and Ethnic Diseases, Ministry of Education, Guizhou Medical University; ${ }^{2}$ Key Laboratory of \\ Medical Molecular Biology, Guizhou Medical University; ${ }^{3}$ Department of Basic Medicine, Guizhou Medical University, \\ Guiyang, Guizhou 550004; ${ }^{4}$ Chinese People's Liberation Army, Secret Service Center Sanatorium of Xiamen, \\ Xiamen, Fujian 361000; ${ }^{5}$ Department of Pathology, Affiliated Hospital of Guizhou Medical University, \\ Guizhou Medical University, Guiyang, Guizhou 550004, P.R. China
}

Received September 20, 2019; Accepted June 4, 2020

DOI: $10.3892 / \mathrm{mmr} .2020 .11253$

\begin{abstract}
Alzheimer's disease (AD) is a chronic neurodegenerative, and abnormal aggregation of the neurotoxic $\beta$ amyloid $(\mathrm{A} \beta)$ peptide is an early event in AD. The present study aimed to determine the correlation between the nicotinic acetylcholine receptor $\alpha 7$ subunit ( $\alpha 7 \mathrm{nAChR})$ and $\mathrm{A} \beta$ in the brains of patients with $\mathrm{AD}$, and to investigate whether the increased expression levels of the $\alpha 7 \mathrm{nAChR}$ could alter the neurotoxicity of $A \beta$. The expression levels of $\alpha 7 \mathrm{nAChR}$ and $\mathrm{A} \beta$ in the brains of patients with $\mathrm{AD}$ and healthy brains were analyzed using immunofluorescence. Moreover, SH-SY5Y cells were used to stably overexpress or silence $\alpha 7 \mathrm{nAChR}$ expression levels, prior to the treatment with or without $1 \mu \mathrm{mol} / 1 \mathrm{~A} \beta_{1-42}$ oligomer $(\mathrm{A} \beta \mathrm{O})$. The mRNA and protein expression levels of $\alpha 7 \mathrm{nAChR}$, synaptophysin (SYP), postsynaptic density of $95 \mathrm{kDa}$ (PSD-95) and synaptosomal-associated protein of $25 \mathrm{kDa}$ (SNAP-25) were subsequently analyzed using reverse transcription-quantitative PCR and western blotting. In addition, the concentration of acetylcholine (ACh) and the activity of acetylcholinesterase (AChE) were analyzed using spectrophotometry, while the cell apoptotic rate was determined using flow cytometry. The expression of $A \beta$ in the brains of patients with $A D$ was found to be significantly increased, whereas the expression of $\alpha 7 \mathrm{nAChR}$ was significantly decreased compared with the healthy control group. In vitro, the expression levels of $\alpha 7$
\end{abstract}

Correspondence to: Professor Xiao-Lan Qi, Key Laboratory of Medical Molecular Biology, Guizhou Medical University, 9 Beijing Road, Guiyang, Guizhou 550004, P.R. China

E-mail: 634826458@qq.com

Key words: SH-SY5Y cells, $\alpha 7$ nicotinic acetylcholine receptor, $\beta$-amyloid peptide, synaptic protein, synaptophysin, apoptotic rate, synaptosomal-associated protein of $25 \mathrm{kDa}$, postsynaptic density of $95 \mathrm{kDa}$, Alzheimer's disease
nAChR were significantly increased or decreased following the overexpression or silencing of the gene, respectively. Consistent with these observations, the mRNA and protein expression levels of SYP, PSD-95 and SNAP-25 were also significantly increased following the overexpression of $\alpha 7$ $\mathrm{nAChR}$ and decreased following the genetic silencing of the receptor. In untransfected or negative control cells, the expression levels of these factors and the apoptotic rate were significantly reduced following the exposure to $A \beta O$, which was found to be attenuated by $\alpha 7 \mathrm{nAChR}$ overexpression, but potentiated by $\alpha 7 \mathrm{nAChR}$ RNA silencing. However, no significant differences were observed in either the $\mathrm{ACh}$ concentration or AChE activity following transfection. Collectively, these findings suggested that $\alpha 7 \mathrm{nAChR}$ may protect the brains of patients with $\mathrm{AD}$ against $\mathrm{A} \beta$, as $\alpha 7$ nAChR overexpression increased the expression levels of SYP, SNAP-25 and PSD-95, and attenuated the inhibitory effect of $A \beta$ on the expression of these synaptic proteins and cell apoptosis. Overall, this indicated that $\alpha 7 \mathrm{nAChR}$ may serve an important neuroprotective role in AD.

\section{Introduction}

Alzheimer's disease (AD) is the most common type of neurodegenerative disorder that affects the older population; it is pathologically characterized by the formation of extracellular senile plaques (SP) and intraneuronal neurofibrillary tangles, which result from the deposition of $\beta$-amyloid peptide (A $\beta$ ) and the aggregation of hyperphosphorylated tau protein, respectively (1). A $\beta$, a peptide of 38-43 amino acids, serves an important role in the pathogenesis of $\mathrm{AD}$ as it aggregates to form soluble oligomers, fibrils and SPs (2). Previous studies have reported that the soluble $A \beta$ oligomer, amyloid peptide oligomers $(\mathrm{A} \beta \mathrm{Os})$, is more toxic than insoluble fibrils $(3,4)$ and is more closely associated with the progression of $\mathrm{AD}(4,5)$. The deposition of $\mathrm{A} \beta$ plaques is also associated with cross-sectional synaptic network dysfunction, progressive brain atrophy, neuronal calcium homeostasis (6) and long term cognitive decline (7). 
Studies conducted on both postmortem brains of individuals with $\mathrm{AD}$ and $\mathrm{AD}$ model animals have reported that that the synapses are affected during the early stages of neurodegenerative processes $(8,9)$. The primary function of the synapse is to mediate intracellular communication by releasing neurotransmitters from the presynaptic terminal, as well as to modulate neural plasticity $(10,11)$. Synaptic proteins, including vesicle-associated and pre- and post-synaptic membrane proteins, are closely related to cognitive function, and previous studies have shown that the loss of synapses in the brain tissues of patients with AD was associated with cognitive impairment (12-14).

Synaptophysin (SYP), a specific marker of vesicles that reflects the density and distribution of synapses, serves a crucial role in neural plasticity by influencing the synaptic structure and mediating neurotransmitter release via phosphorylation (15). Synaptosomal-associated protein of $25 \mathrm{kDa}$ (SNAP-25), a component of the complex of soluble $\mathrm{N}$-ethylmaleimides sensitive factor attachment protein receptor proteins, is central to synaptic vesicle exocytosis, a process that regulates intracellular calcium dynamics by negatively modulating neuronal voltage-gated calcium channels (16). Postsynaptic density of $95 \mathrm{kDa}$ (PSD-95), a neuronal PSD-95/Dlg/ZO-1 protein, associates with receptors and cytoskeletal elements at synapses, orchestrates synaptic development and regulates synapse stabilization and plasticity (17). Notably, numerous studies have demonstrated that certain chemicals, such as A $\beta O$ s, can alter the levels of SYP in SH-SY5Y cells, which may be related to the pathogenesis of AD (18-20).

Previous studies have revealed that cholinergic deficits, such as the modification of acetylcholine (ACh) and cholinesterase (ChE), as well as the downregulated expression of nicotinic $\mathrm{ACh}$ receptors ( $\mathrm{AAChRs}$ ), are all significant contributors to cognitive impairment in AD $(21,22)$. ACh is stored in the synaptic vesicles and is exocytosed and released into the synaptic cleft to activate nAChRs; activated nAChRs are highly permeable to $\mathrm{Ca}^{2+}$, which is an important signaling molecule involved in the long-lasting modulatory effects of the receptors (21). There are two forms of ChE, acetylcholinesterase (AChE) and butyrylcholinesterase (BuChE). It was previously demonstrated that AChE C-terminal peptides modify the regulation of nAChRs (23), which is consistent with another study that reported treatment with an $\mathrm{AChE}$ inhibitor increased nAChR expression levels (24). Neuronal nAChRs, members of the super-family of ligand-gated ion channels, are involved in a number of important physiological functions, such as memory and cognition (25). The loss of these receptors from several regions of brains affected by AD is observed in receptor-ligand binding studies, and this loss is positively correlated with the presence of SPs in the temporal lobe (26). The $\alpha(\alpha 2-\alpha 10)$ and $\beta(\beta 2-\beta 4)$ subunits of these receptors combine to form both hetero- and homo-pentameric subtypes, of which $\alpha 4 \beta 2$ and $\alpha 7 \mathrm{nAChRs}$ are the predominant subtypes in human brains (27). Moreover, neuronal nAChRs are expressed pre-, post- and extra-synaptically in the brains and mediate postsynaptic responses (28). Notably, electrophysiological studies have shown that the formation of glutamatergic synapses in the hippocampus is promoted by $\alpha 7 \mathrm{nAChR}$ (29). It has been suggested that $\alpha 3$ and $\alpha 7 \mathrm{nAChR}$ may change the neuroinflammatory status by inhibiting NF- $x \mathrm{~B}$ activation and reducing the production of inflammatory cytokines (30-32).
An early sign of $\mathrm{AD}$ is the loss of synapses, which is most strongly correlated with cognitive decline (33). Another characteristic of $\mathrm{AD}$, as demonstrated by positron emission tomography, is a deficit of nAChRs in the brain, which is also closely related to cognitive dysfunction (34). In a previous study conducted in $\alpha 7 \mathrm{nAChR}$ knockout mice, the number of glutamatergic synapses in the hippocampus was severely reduced, whereas the activation of endogenous $\alpha 7 \mathrm{nAChR}$ was found to increase this number (29); however, the effects of altered $\alpha 7 \mathrm{nAChR}$ expression on the synaptic proteins are relatively unknown.

The present study aimed to determine whether the altered expression levels of $\alpha 7 \mathrm{nAChR}$ in SH-SY5Y cells may regulate the expression levels of SYP, PSD-95 and SNAP-25, in addition to their influence on the neurotoxic effect of $A \beta$ on these synaptic proteins, cell apoptosis, and the levels and activity of $\mathrm{ACh}$ and $\mathrm{AChE}$.

\section{Materials and methods}

Chemicals and reagents. The anti- $\alpha 7 \mathrm{nAChR}$ rabbit polyclonal antibody (cat. no. GTX10096), anti- $\alpha 7$ nAChR rabbit polyclonal antibody (cat. no. GTX64511), fluorescent FITC-conjugated anti-rabbit IgG antibody (cat. no. BA1105), fluorescence Cy3-conjugated anti-mouse IgG antibody (cat. no. BA1031), anti-SNAP-25 rabbit monoclonal antibody (cat. no. GTX62566) and the anti-SD-95 rabbit monoclonal antibody (cat. no. GTX61948) were all purchased from GeneTex, Inc. The anti-A $\beta$ mouse polyclonal antibody (cat. no. 803001) was purchased from BioLegend, Inc., and the anti-SYP rabbit monoclonal antibody (cat. no. ab32127) was obtained from Abcam. The horseradish peroxidase (HRP)-conjugated anti-rabbit IgG antibody (cat. no. 7074) was purchased from Cell Signaling Technology, Inc., while the HRP-conjugated anti-mouse IgG antibody (cat. no. SC-2005) and anti- $\beta$-actin mouse monoclonal antibody (cat. no. SC-81178) were obtained from Santa Cruz Biotechnology, Inc.

Control short hairpin RNA (shRNA) plasmid-B (cat. no. SC-108065), $\alpha 7$ nAChR shRNA plasmid (h; cat. no. SC-42532-sh) and GFP shRNA plasmid (A.vic; cat. no. SC-45924-sh) were purchased from Santa Cruz Biotechnology, Inc. E.coli DH5 $\alpha$ competent cells purchased from Beijing Solarbio Science and Technology Co., Ltd. The Alexa 488-conjugated goat anti-rabbit IgG antibody, DMEM and FBS were obtained from Thermo Fisher Scientific, Inc. The pcDNA3.1 plasmid, G418 solution, X-treme GENE HP DNA Transfection reagent, First Start Universal SYBR Green Master mix (Rox) and First Strand cDNA Synthesis kit were obtained from Roche Diagnostics GmbH. The Annexin V-APC/7-AAD apoptosis kit was purchased from Multi Sciences, while the Hyper Performance Chemiluminescence film and ECL Plus reagent were obtained from Cytiva. AChE assay kits (cat. no. A024-1-1) and ACh assay kits (cat. no. A105-3) were obtained from Nanjing Jiancheng Bioengineering Institute and the quantitative (q)PCR primer pairs for $\alpha 7 \mathrm{nAChR}$, SYP, PSD-95, SNAP-25 and $\beta$-actin were designed based on the corresponding gene sequences and synthesized by Shanghai Genecore Bio Technologies Co., Ltd. DMEM and FBS purchased from Thermo Fisher Scientific, Inc. The pcDNA3.1-GFP plasmid was kindly donated by 
Professor Jian-Jiang Zhou of Guizhou Medical University (Guizhou, China), while $A \beta_{1-42}$, puromycin, 1,1,1,3,3,3- hexafluoro-2-propanol (HFIP), goat serum, DMSO and the other general chemicals used were purchased from Sigma-Aldrich; Merck KGaA.

Patient samples. The study was approved by the Ethics Committee of the Affiliated Hospital of Guizhou Medical University. All the brain tissue blocks had been donated voluntarily by the patient or with the consent of the family. Post-mortem brain samples from the Netherlands Brain Bank were obtained and characterized according to the specific clinical and neuropathological criteria (35). According to their medical history, clinical manifestations and laboratory tests, the donor was diagnosed as 'probable AD' by excluding other possible causes of dementia, such as stroke. The clinical diagnosis was performed according to the National Institute of Neurological and Communication Disorders and Stroke and the Association of Alzheimer's Disease and Related Diseases criteria (36), and the severity of dementia was assessed according to the Global Deterioration Scale (37). The control brain samples had no known history or symptoms of any neurological or psychiatric disorder.

The temporal cortex, frontal cortex and hippocampus of nine patients with $\mathrm{AD}$ (men, 3; women, 6; age range, 70-100 years) and nine controls (men, 4; women, 5; age range, 65-100 years) were studied; the mean age at mortality for the patients with $\mathrm{AD}$ was $81.5 \pm 7.1$ years, while the mean age at mortality of the controls was $79.4 \pm 9.2$ years. The interval between mortality and autopsy in the patients with AD and the controls was $5.1 \pm 1.0$ and $8.0 \pm 3.4 \mathrm{~h}$, respectively.

$A \beta O$ preparation. Synthetic human $A \beta_{1-42}$ was suspended in pre-cooled HFIP at a final concentration of $1 \mathrm{mM}$; the solution was incubated at room temperature for $60 \mathrm{~min}$ and subsequently on ice for $10 \mathrm{~min}$ (38). Aliquots were transferred into non-siliconized microcentrifuge tubes and the HFIP was allowed to evaporate overnight in a hood at room temperature, which was then stored at $-80^{\circ} \mathrm{C}(38)$. Prior to the treatment of cells, $A \beta_{1-42}$ was dissolved in DMSO to obtain a final concentration of $5 \mathrm{mmol} / \mathrm{l}$. For the preparation of oligomers, the solution was subsequently diluted with modified DMEM and incubated for $24 \mathrm{~h}$ at $4^{\circ} \mathrm{C}$.

Double-labelling immunofluorescence. The co-localization of $\alpha 7 \mathrm{nAChR}$ and $\mathrm{A} \beta$ was analyzed using double staining. Human brain tissue wax blocks were provided by the Netherlands Brain Bank, and were cut into 6- $\mu \mathrm{m}$ sections. The sections were heated at $58^{\circ} \mathrm{C}$ for $1 \mathrm{~h}$, placed in xylene I, xylene II, xylene III (15 min each) and $100 \%$ ethanol (10 min), $90 \%$ ethanol (10 min), 70\% ethanol (10 min), deparaffinized and hydrated. After three washes in PBS and microwaving in $0.01 \mathrm{M}$ citric acid buffer ( $\mathrm{pH} 6.0$ ) at $70^{\circ} \mathrm{C}$ for $20 \mathrm{~min}$ for the antigen repair, sections were subsequently blocked with goat serum for $1 \mathrm{~h}$ at $37^{\circ} \mathrm{C}$ prior to incubation with primary antibodies against $\alpha 7 \mathrm{nAChR}$ (1:100) and $\mathrm{A} \beta$ (1:100) overnight at $4^{\circ} \mathrm{C}$. Following the primary antibody incubation, the sections were washed three times in PBS and incubated with either a FITC-conjugated goat anti-mouse IgG antibody (1:100) or a Alexa 488-conjugated goat anti-rabbit IgG antibody (1:100) for $1 \mathrm{~h}$ at room temperature. The sections were subsequently rinsed three times in PBS and mounted with VECTASHIELD (Vector Laboratories, Inc.).

The immunofluorescence procedure was performed by an independent neuropathologist and the analysis of the results were performed by another researcher. The brain regions analyzed included the hippocampus, temporal lobe and frontal lobe. The integrated optical density (IOD) of immunofluorescence staining for $\alpha 7 \mathrm{nAChR}$ and $\mathrm{A} \beta$ was determined by counting randomly selected nine fields of vision using a fluorescent microscope (magnification, x200 or x400).

Cell culture and treatments. SH-SY5Y cells, derived from human neuroblastoma cells, were purchased from the German Collection of Microorganisms and Cell Cultures $\mathrm{GmbH}$. Cells were cultured in DMEM, supplemented with $10 \%$ FBS, $100 \mathrm{mg} / \mathrm{ml}$ streptomycin and $100 \mathrm{U} / \mathrm{ml}$ penicillin, and maintained in a humidified atmosphere containing $5 \% \mathrm{CO}_{2}$ at $37^{\circ} \mathrm{C}$. To maintain their neuronal characteristics, the cells were treated following $\leq 3$ passages with $1 \mathrm{mM} \mathrm{A} \beta \mathrm{O}$ at $37^{\circ} \mathrm{C}$ for $24 \mathrm{~h}$, in combination with the knockdown or overexpression of $\alpha 7 \mathrm{nAChR}$.

Construction of the pcDNA3.1- $\alpha 7$ nAChR expression plasmid. Total RNA was extracted from the SH-SY5Y cells using TRIzol ${ }^{\circledR}$ reagent (Invitrogen; Thermo Fisher Scientific, Inc.), according to the manufacturer's protocol. A total of $1 \mu \mathrm{g}$ RNA was reverse transcribed into cDNA using a First Strand cDNA synthesis kit. The following primers pairs were used for reverse transcription (RT-)qPCR, which were designed according to the GenBank sequence no. BC-037571: $\alpha 7 \mathrm{nAChR}$ forward, 5'-CCCAAGCTTATGCAGGAGGCAGATATCAGTGGC-3' and reverse, 5'-CGCGGATCCTTACGCAAAGTCTTTGGA CACG-3'. The final PCR product obtained was 966-bp long. The final PCR products were subsequently separated by $1 \%$ agarose gel electrophoresis and the 966-bp fragment was purified using an agarose gel extraction kit. This fragment was then ligated into the pcDNA3.1 plasmid to create the recombinant pcDNA3.1- $\alpha 7 \mathrm{nAChR}$ plasmid, which was amplified in competent $E$. coli DH5a cells. The pcDNA3.1- $\alpha 7$ nAChR plasmid was subsequently purified, digested with Hind III (1 $\mu \mathrm{l})$ and $\mathrm{BamHI}(1 \mu \mathrm{l})$ at $37^{\circ} \mathrm{C}$ for $1 \mathrm{~h}$ in a water bath, visualized with ethidium bromide and detected using agarose gel electrophoresis. The plasmid was sequenced by Sangon Biotech Co., Ltd. to validate its identity.

Transfection of the pcDNA3.1- $\alpha 7 n A C h R$ or $\alpha 7 n A C h R$ shRNA plasmid (h) into SH-SY5Y cells and selection of stable clones. SH-SY5Y cells, maintained and cultured aforementioned, were stably transfected with the pcDNA3.1- $\alpha 7$ nAChR, empty pcDNA 3.1, pcDNA 3.1-GFP, control shRNA, $\alpha 7$ nAChR shRNA plasmid (h) or GFP shRNA plasmid using X-treme GENE HP DNA Transfection reagent, according to the manufacturer's protocol. The pcDNA 3.1 and control shRNA plasmid-B, which do not target any endogenous transcript, were used as negative controls, and pcDNA 3.1-GFP and GFP shRNA plasmids served as the controls for the efficiency of transfection.

After $24 \mathrm{~h}$ of transfection incubation at $37^{\circ} \mathrm{C}, 1 \times 10^{3}$ cells $/ \mathrm{ml}$ transfected with pcDNA $3.1-\alpha 7 \mathrm{nAChR}(1.5 \mathrm{mg} / \mathrm{ml})$ and pcDNA $3.1(1.5 \mathrm{mg} / \mathrm{ml})$ were selected for $800 \mu \mathrm{g} / \mathrm{ml} \mathrm{G} 418$ administra- 
Table I. Primers used for determining the level of mRNA encoding $\alpha 7 n$ AChR, SYP, PSD-95, SNAP- 25 or $\beta$-actin by reverse transcription-quantitative PCR.

\begin{tabular}{|c|c|c|c|}
\hline Gene & Primer sequence & Amplicon size (bp) & Annealing temperature $\left({ }^{\circ} \mathrm{C}\right)$ \\
\hline$\alpha 7 \mathrm{nAChR}$ & $\begin{array}{l}\text { 5'ACCACTCACCGTCTACTTCTCC } 3 \text { ' } \\
\text { 5'CATCTGGGAAACGAACAGTCTT } 3 \text { ' }\end{array}$ & 167 & 58 \\
\hline SYP & $\begin{array}{l}\text { 5'GCTGTCAGATGTGAAGATGGC 3' } \\
\text { 5'CCTGTCTCCTTAAACACGAACC 3' }\end{array}$ & 192 & 52 \\
\hline PSD-95 & $\begin{array}{l}\text { 5' CTCAGGGTCAACGACAGCAT 3' } \\
\text { 5' GACATAGAGGCGAACGATGG 3' }\end{array}$ & 114 & 58 \\
\hline SNAP-25 & $\begin{array}{l}\text { 5' GGATATGGGCAATGAGATCG 3' } \\
\text { 5' CAGCATCTTTGTTGCACGTT 3' }\end{array}$ & 115 & 58 \\
\hline$\beta$-actin & $\begin{array}{l}\text { 5'TGGCACCACACCTTCTACAATG3' } \\
\text { 5'TCATCTTCTCGCGGTTGGC 3' }\end{array}$ & 103 & 58 \\
\hline
\end{tabular}

tion for 14 days at $37^{\circ} \mathrm{C}$, while cells transfected with control shRNA plasmid-B or $\alpha 7$ nAChR shRNA plasmid (h) were selected for $4 \mu \mathrm{g} / \mathrm{ml}$ puromycin administration 14 days at $37^{\circ} \mathrm{C}$. When resistant cell clones appeared, individual clones were collected and re-cultured to $60-80 \%$ confluence in successive passages until cells demonstrated the overexpression or genetic silencing of $\alpha 7 \mathrm{nAChR}$. Subsequent experimentations were performed after $24 \mathrm{~h}$.

Analysis of mRNA encoding the $\alpha 7 n A C h R$ subunit, SYP, $P S D-95$ and SNAP-25 using RT-qPCR. The mRNA expression levels of the $\alpha 7 \mathrm{nAChR}$ subunit, SYP, PSD-95, SNAP-25 and $\beta$-actin were determined using RT-qPCR, according to the manufacturer's instructions of each kit or reagent. Cells were collected for RNA extraction when the cell density reached $80 \%$. In brief, $1 \mu \mathrm{g}$ total RNA was extracted from the SH-SY5Y cells using TRIzol ${ }^{\circledR}$ reagent (Invitrogen; Thermo Fisher Scientific, Inc.) and the reverse transcription of RNA to cDNA was performed using a First Strand cDNA synthesis kit at $42^{\circ} \mathrm{C}$ for $60 \mathrm{~min}, 70^{\circ} \mathrm{C}$ for $5 \mathrm{~min}$ and $4^{\circ} \mathrm{C}$ for $10 \mathrm{~min}$. qPCR was subsequently performed using an ABI Step One Plus system and First Start Universal SYBR Green Master (ROX), with the following thermocycling conditions: Initial denaturation at $95^{\circ} \mathrm{C} 10 \mathrm{~min}$, followed by 40 cycles at $95^{\circ} \mathrm{C}$ for $15 \mathrm{sec}$, annealing temperature for $60 \mathrm{sec}$ and $72^{\circ} \mathrm{C}$ for $60 \mathrm{sec}$. The primer pairs for $\alpha 7 \mathrm{nAChR}, \mathrm{SYP}, \mathrm{PSD}-95, \mathrm{SNAP}-25$ or $\beta$-actin are presented in Table I. Expression levels were determined using the $2^{-\Delta \Delta C q}$ method (39). The experiment was repeated nine times independently and were quantified using SDS v1.4 software (Applied Biosystems; Thermo Fisher Scientific, Inc.).

Analysis of the $\alpha 7$ nAChR subunit, SYP, PSD-95 and SNAP-25 expression levels using western blotting. The protein expression levels of $\alpha 7 \mathrm{nAChR}$, SYP, PSD-95 and SNAP-25 in cell lysates were quantified using western blotting. Cells were washed three times with pre-chilled PBS in a 6-well plate. Then, cells were incubated on ice for $3 \mathrm{~h}$ with $60 \mu \mathrm{l} /$ well RIPA buffer containing protease and phosphatase inhibitors (cat. no. P0013B; Beyotime Institute of Biotechnology). The supernatant was collected after centrifugation at $4^{\circ} \mathrm{C}$ for $15 \mathrm{~min}$ at
$4,024.8 \mathrm{x} \mathrm{g}$, and the concentration of the supernatant protein was assessed with a Bradford Protein Assay kit (cat. no. P0006; Beyotime Institute of Biotechnology), according to the manufacturer's instructions. Proteins were loaded $(12 \mu \mathrm{g} / \mathrm{lane})$ and proteins were separated by $10 \%$ SDS-PAGE. The separated proteins were transferred to PVDF membranes and blocked with $5 \%$ fat-free dry milk at room temperature for $2 \mathrm{~h}$. The membranes were incubated with primary antibodies against $\alpha 7 \mathrm{nAChR}$ (1:200), SYP(1:500), PSD-95 (1:500) and SNAP-25 $(1: 200)$ at $4^{\circ} \mathrm{C}$ overnight. Following the primary antibody incubation, Membranes were washed three times with TBS buffer with $0.1 \%$ Tween-20 and subsequently incubated with a HRP-conjugated secondary antibody [1:5,000 (anti-mouse) or 1:2,000 (anti-rabbit)] at room temperature for $1 \mathrm{~h}$. Protein bands were detected with an ECL kit, according to the manufacturer's instructions. After stripping these antibodies with buffer containing detergent (cat. no. P0025; Beyotime Institute of Biotechnology), the membranes were probed again with antibodies against $\beta$-actin $(1: 6,000)$ at $37^{\circ} \mathrm{C}$ for $2 \mathrm{~h}$ and then incubated with a HRP-conjugated anti-mouse IgG secondary antibody $37^{\circ} \mathrm{C}$ for $60 \mathrm{~min}$. Expression levels of the target proteins were normalized to $\beta$-actin and the resulting ratio was presented as a percentage of the corresponding control value. Semi-quantification was performed using ImageJ software (v1.46; National Institutes of Health).

Flow cytometric analysis of apoptosis. Cell apoptosis was determined using an Annexin V-APC/7-AAD apoptosis kit, according to the manufacturer's protocol. Cells were harvested and washed three times with pre-cooled PBS. Following centrifugation at $400.8 \mathrm{xg}$ at room temperature for $5 \mathrm{~min}$, cells were resuspended in $500 \mu$ l binding buffer containing $5 \mu 1$ Annexin V-APC and $10 \mu 1$ 7-ADD and incubated in the dark at room temperature for $5 \mathrm{~min}$. Apoptotic cells were analyzed using a BD FACSVerse flow cytometer (BD Biosciences) and FlowJo software (FlowJo LLC; v.10.6.2). Results are presented as the percentage of early + late apoptotic cells.

Analysis of the concentration of ACh and the activity of AChE in cell supernatant using spectrophotometry. The concentra- 
A
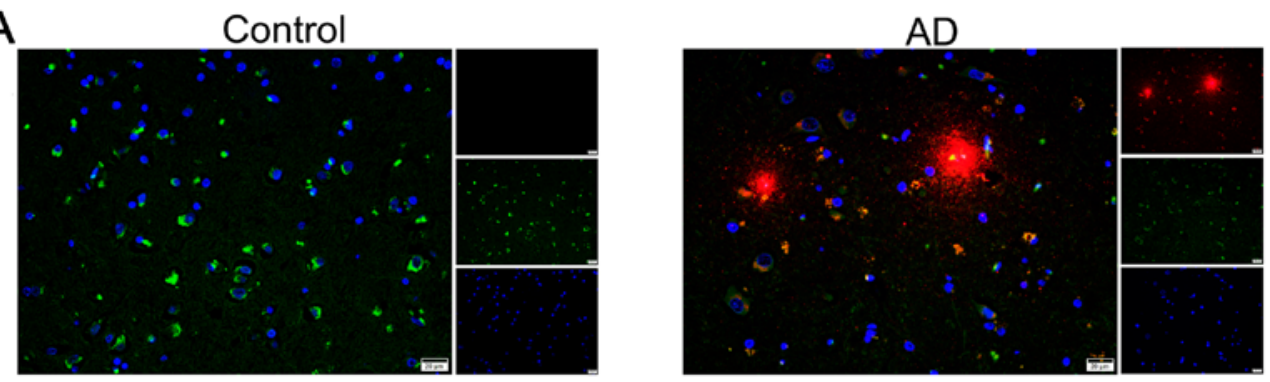

Temporal cortex
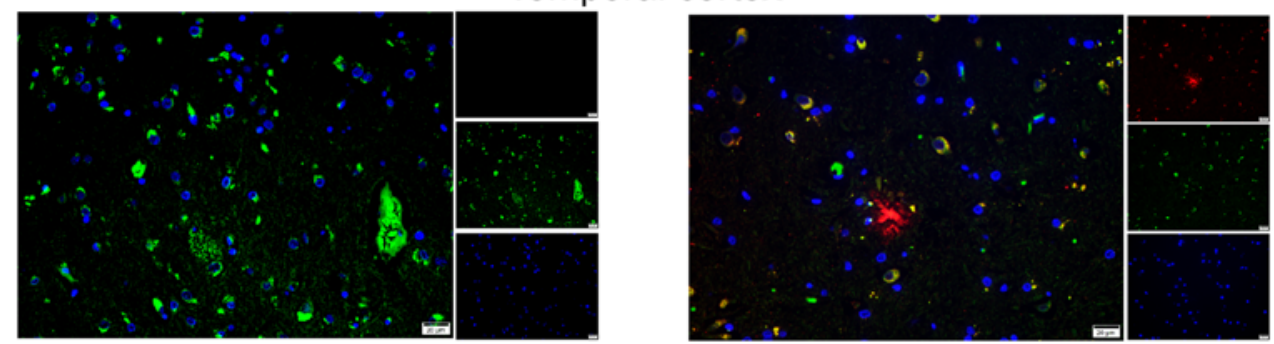

Frontal cortex
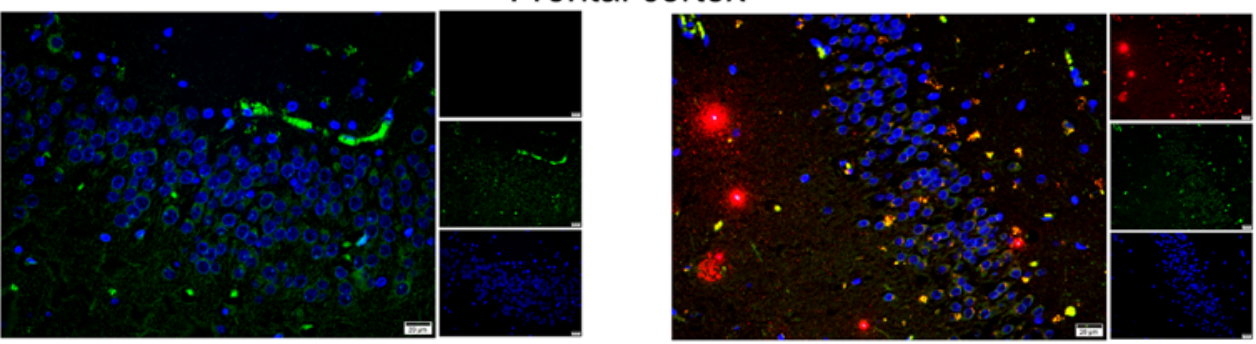

Hippocampus
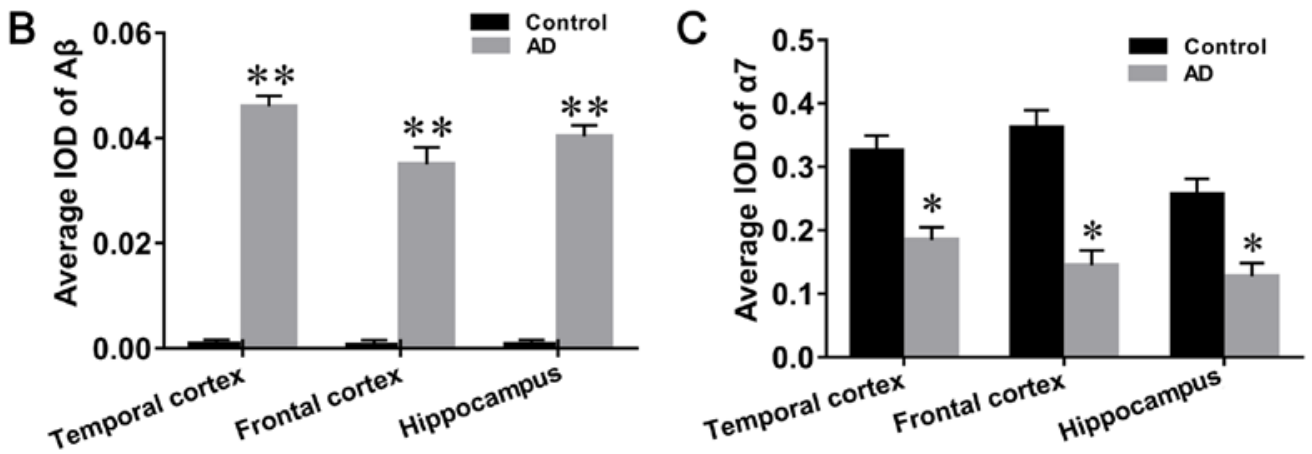

Figure 1. Expression levels of $\alpha 7 \mathrm{nAChR}$ and $\mathrm{A} \beta$ in the brains of patients with AD and normal brains. (A) Images of the immunofluorescence double staining in the control and AD groups. (B) A $\beta$ is expressed in the cytoplasm and extracellular matrix of cells. It was also found highly expressed in the brain slices of patients with $\mathrm{AD}$, whereas the expression levels were minimal in healthy control brain sections following immunofluorescence double staining. (C) $\alpha 7 \mathrm{nAChR}$ was found expressed in the cytoplasm and reduced expression levels were observed in brain sections of patients with AD compared with healthy human brain sections, following immunofluorescence double staining. The cell nuclei are stained in blue using DAPI. A $\beta$-positive neurons are indicated in red and $\alpha 3 \mathrm{nAChR}$-positive neurons are green. Scale bar, $20 \mu \mathrm{m}$. Data are presented as the mean \pm standard deviation ( $\mathrm{n}=9$ ). ${ }^{*} \mathrm{P}<0.05$ and ${ }^{* *} \mathrm{P}<0.01 \mathrm{vs}$. control group. $\alpha 7 \mathrm{nAChR}$, nicotinic acetylcholine receptor $\alpha 7$ subunit; $\mathrm{A} \beta, \beta$-amyloid; AD, Alzheimer's disease; IOD, integrated optical density.

tion of ACh and activity of AChE were measured according to manufacturer's protocol of the AChE assay kits and ACh assay kits. The substrate solution was reacted with $\mathrm{ACh}$ at room temperature for $15 \mathrm{~min}$ to produce a brown compound. ACh was synthesized by choline and acetyl-CoA under the catalytic action of choline acetyl translocase (choline acetylase). The absorbance OD value was measured at $550 \mathrm{~nm}$, with the depth of color being proportional to the concentration of ACh.

$\mathrm{AChE}$ is mainly located in the synaptic space of cholinergic nerve terminals and is released under biological stimulation (40). AChE hydrolyzed ACh to cholic acid and acetic acid, and subsequently choline was reacted with mercapto color reagent to produce a 5-thio-2-nitro-benzoic acid anion, which produced a yellow color. The catalytic activity of AChE was measured at a wavelength of $412 \mathrm{~nm}$.

Statistical analysis. Statistical analysis was performed using SPSS v22.0 software (IBM Corp.) and data are presented as the mean \pm standard deviation. Pearson correlation analysis was used to determine the correlation, statistical differences between two groups were determined using a two-tail Student's $\mathrm{t}$-test and statistical differences between multiple groups 

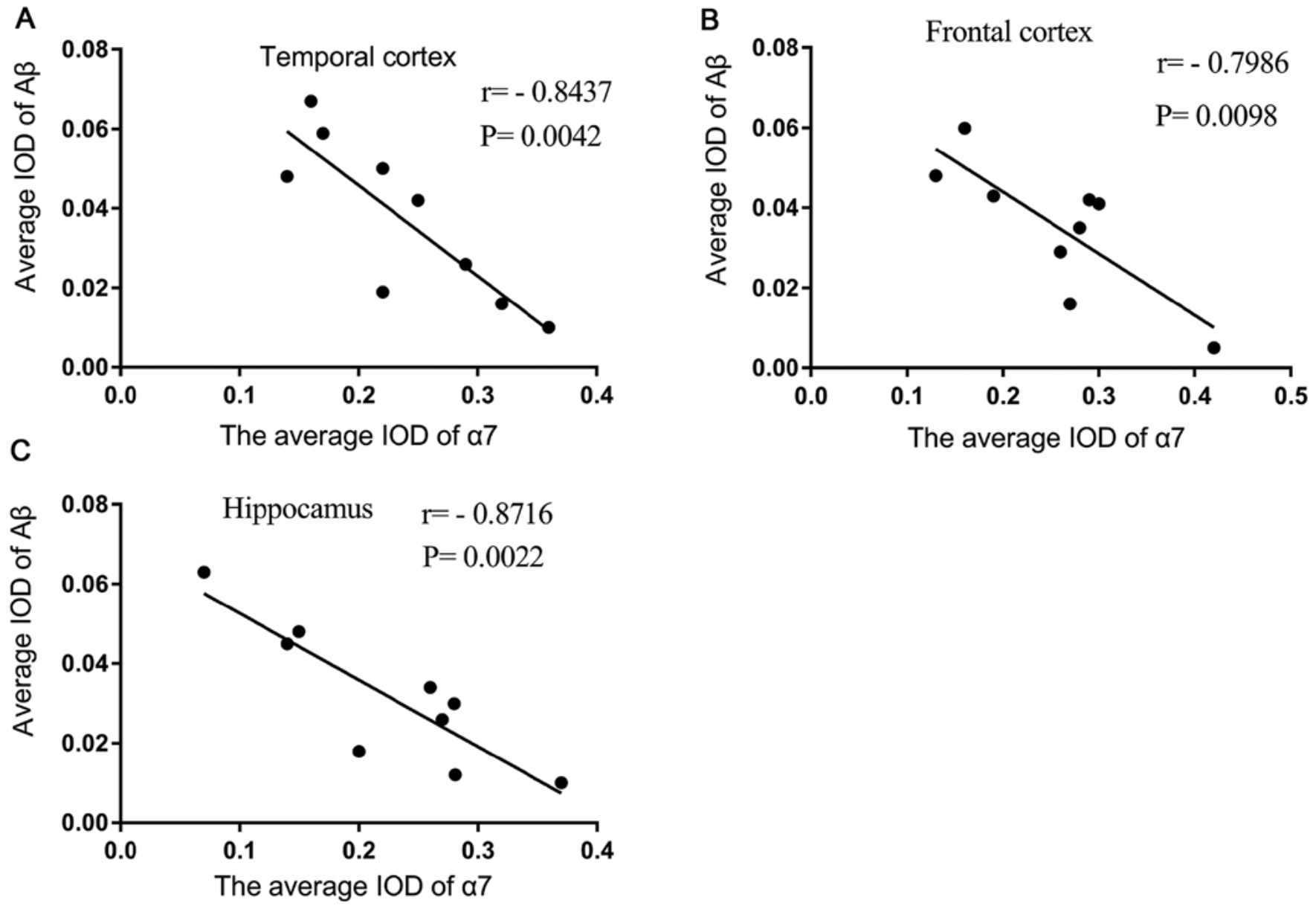

Figure 2. Mean IOD of $\alpha 7 \mathrm{nAChR}$ is negatively correlated with the mean IOD of $\mathrm{A} \beta$ in the brain of patients with AD. Mean IOD of $\alpha 7 \mathrm{nAChR}$ and $\mathrm{A} \beta$ were found to be negatively correlated with each other in the (A) temporal cortex, (B) frontal cortex and (C) hippocampus following immunofluorescence double staining of brain slices of patients with AD. Data was obtained using correlation analysis ( $\mathrm{n}=9$ ). $\mathrm{P}<0.05 \alpha 7 \mathrm{nAChR}$ vs. A $\beta$. IOD, integrated optical density; $\alpha 7$ $\mathrm{nAChR}$, nicotinic acetylcholine receptor $\alpha 7$ subunit; $\mathrm{A} \beta, \beta$-amyloid; $\mathrm{AD}$, Alzheimer's disease.

were determined using a one-way ANOVA followed by a Student-Newman-Keuls or Tukey's post hoc test $(\mathrm{n}=9)$. $\mathrm{P}<0.05$ was considered to indicate a statistically significant difference.

\section{Results}

Expression levels of $\alpha 7 n A C h R$ and $A \beta$ in the brains of patients with $A D$ and healthy brains. $\mathrm{A} \beta$ was observed to be expressed mainly in the cytoplasmic and extracellular forms of both hippocampal and cortical neurons (Fig. 1A), and was found to be expressed at high levels in the brain of patients with AD compared with the controls (Fig. 1B). $\alpha 7 n$ AChR was observed to be mainly expressed in the cytoplasm of hippocampal and cortical nerves (Fig. 1A), and its distribution in the brain of patients with AD was significantly decreased compared with the healthy control group (Fig. 1C).

Mean IOD of $\alpha 7 n A C h R$ is negatively correlated with the mean IOD of $A \beta$ in the brains of patients with $A D$. The mean IOD of $\alpha 7 \mathrm{nAChR}$ and $\mathrm{A} \beta$ observed by immunofluorescence double staining were demonstrated to be strongly negatively correlated with each other in the temporal cortex (Fig. 2A), frontal cortex (Fig. 2B) and hippocampus (Fig. 2C) of brain sections of patients with AD.
Expression levels of $\alpha 7 n A C h R$ mRNA and protein in SH-SY5Y cells in which $\alpha 7 n A C h R$ is overexpressed or silenced. Compared with both untransfected cells (normal control) and those transfected with the empty plasmid (negative control), the mRNA and protein expression levels of the $\alpha 7 \mathrm{nAChR}$ subunit (Fig. 3A and B) in cells overexpressing the receptor were increased by 433 and $110 \%$, respectively, in SH-SY5Y cells. Moreover the mRNA and protein expression levels were reduced by $95 \%$ (Fig. 3C) and $80 \%$ (Fig. 3D), respectively, following the genetic silencing of $\alpha 7 \mathrm{nAChR}$.

$m R N A$ and protein expression levels of SYP, PSD-95 and SNAP-25 in SH-SY5Y cells in which $\alpha 7 n A C h R$ is overexpressed or silenced. Compared with untransfected controls and cells transfected with the empty plasmid, the mRNA and protein expression levels of SYP, PSD-95 and SNAP-25 were significantly increased in SH-SY5Y cells overexpressing $\alpha 7$ nAChR (Fig. 4A-C). Furthermore, the mRNA and protein expression levels of SYP, PSD-95 and SNAP-25 were significantly decreased in SH-SY5Y cells in which $\alpha 7 \mathrm{nAChR}$ was silenced (Fig. 4D-F).

Concentration of ACh and the activity of AChE in SH-SY5Y cells in which the expression of $\alpha 7 n A C h R$ is overexpressed 


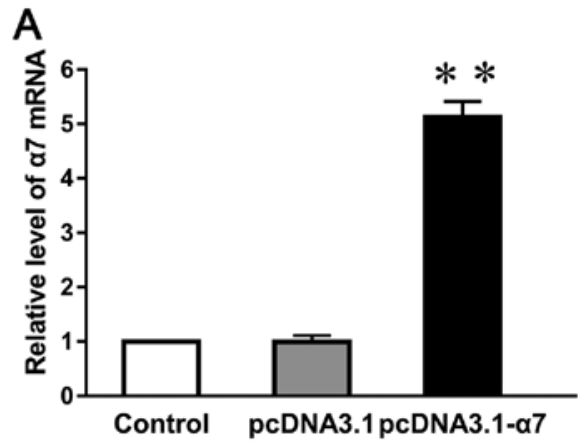

B

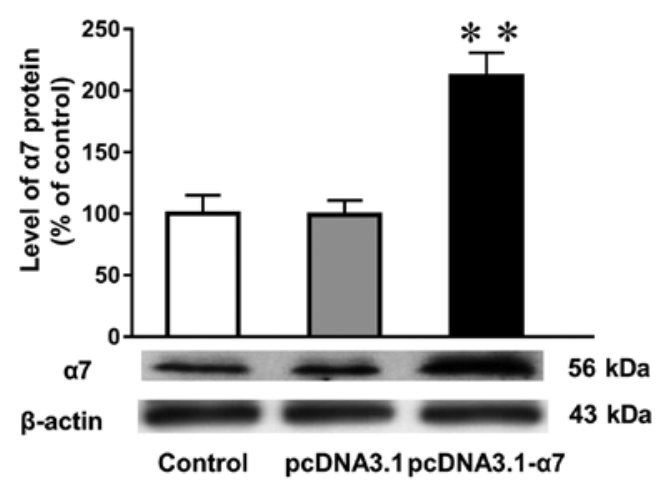

C

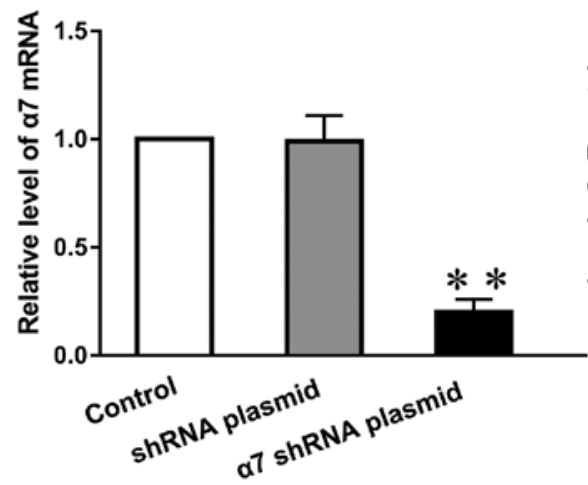

D

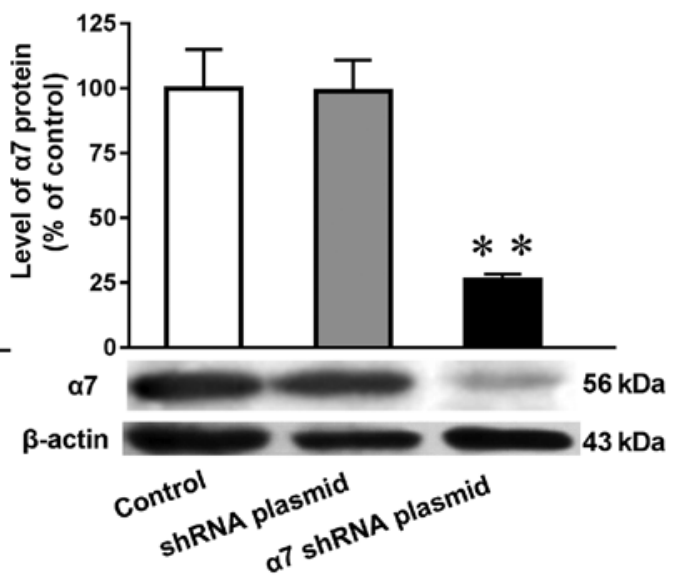

Figure 3. Expression levels of $\alpha 7 \mathrm{nAChR}$ mRNA and protein in SH-SY5Y cells in which $\alpha 7 \mathrm{nAChR}$ is overexpressed or silenced. (A) mRNA and (B) protein expression levels of $\alpha 7 \mathrm{nAChR}$ in SH-SY5Y cells overexpressing $\alpha 7 \mathrm{nAChR}$. (C) mRNA and (D) protein expression levels of $\alpha 7 \mathrm{nAChR}$ in SH-SY5Y cells with silenced $\alpha 7 \mathrm{nAChR}$ expression. $\beta$-actin was used as an internal standard. Expression levels were determined using reverse transcription-quantitative PCR and western blotting. Data are presented as the mean \pm standard deviation $(n=9){ }^{* *} \mathrm{P}<0.01$ vs. control. $\alpha 7 \mathrm{nAChR}$, nicotinic acetylcholine receptor $\alpha 7$ subunit; shRNA, short hairpin RNA.

or silenced. No significant differences were observed in the concentration of ACh or the activity of AChE in SH-SY5Y cells with overexpressed or silenced $\alpha 7 \mathrm{nAChR}$ expression compared with the control cells (Table II).

mRNA and protein expression levels of SYP, PSD-95 and SNAP-25 in SH-SY5Y cells in which $\alpha 7 n A C h R$ is overexpressed or silenced and exposed to $A \beta O$. Compared with the untransfected control or negative control, the mRNA and protein expression levels of SYP, PSD-95 and SNAP-25 were significantly decreased following the exposure to $\mathrm{A} \beta \mathrm{O}$ compared with the control group (Fig. 5A-F). In addition, the overexpression of $\alpha 7 \mathrm{nAChR}$ attenuated the toxicity of $\mathrm{A} \beta \mathrm{O}$ (Fig. 5A-C), while $\alpha 7 \mathrm{nAChR}$ silencing potentiated the toxic effects induced by $\mathrm{A} \beta \mathrm{O}$ (Fig. 5D-F).

Apoptotic rate of SH-SY5Y cells in which the expression of $\alpha 7 n A C h R$ is overexpressed or silenced and simultaneously exposed to $A \beta O$. To investigate the neurotoxic effects of $\mathrm{A} \beta \mathrm{O}$ on cell apoptosis and the neuroprotective function of $\alpha 7$ $\mathrm{nAChR}$, the apoptotic rate was determined using an Annexin V-APC/7AAD apoptosis kit and flow cytometry (Fig. 6A). The results demonstrated that the apoptotic rates were significantly increased in SH-SY5Y cells treated with $\mathrm{A} \beta \mathrm{O}$, and that the overexpression of $\alpha 7 \mathrm{nAChR}$ attenuated the A $\beta O$-induced apoptotic rate, whereas $\alpha 7 \mathrm{nAChR}$ silencing increased the $\mathrm{A} \beta \mathrm{O}$-induced apoptotic rate (Fig. 6B).

\section{Discussion}

The present study successfully established cell lines stably transfected with either the pcDNA3.1- $\alpha 7$ nAChR or $\alpha 7$ nAChR shRNA plasmid, and subsequently demonstrated that the mRNA and protein expression levels of $\alpha 7 \mathrm{nAChR}$ were significantly increased and decreased, respectively. In the present study, the levels of upregulation and downregulation of $\alpha 7 \mathrm{nAChR}$ were not consistent. Since not all post-transcriptional products are translated into proteins, the increase of mRNA is not necessarily synchronized with the expression of proteins. Under different conditions of up- and downregulation, the efficiency of transcription and translation differs.

Previous studies have shown that alterations in nicotinic cholinergic mechanisms contribute to brain dysfunction (41). $\mathrm{ACh}$ is degraded by $\mathrm{AChE}$ to choline at cholinergic synapses to modulate synaptic transmission, and choline is suggested to be a full agonist of $\alpha 7 \mathrm{nAChR}$ (42). A previous study revealed that an $\alpha 7 \mathrm{nAChR}$ agonist increased the release of ACh transiently (43). In the present study, the effects of the 
A
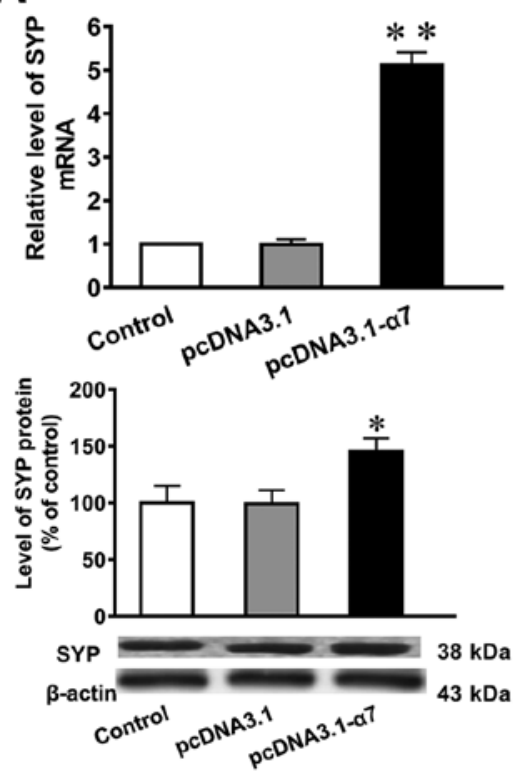

D
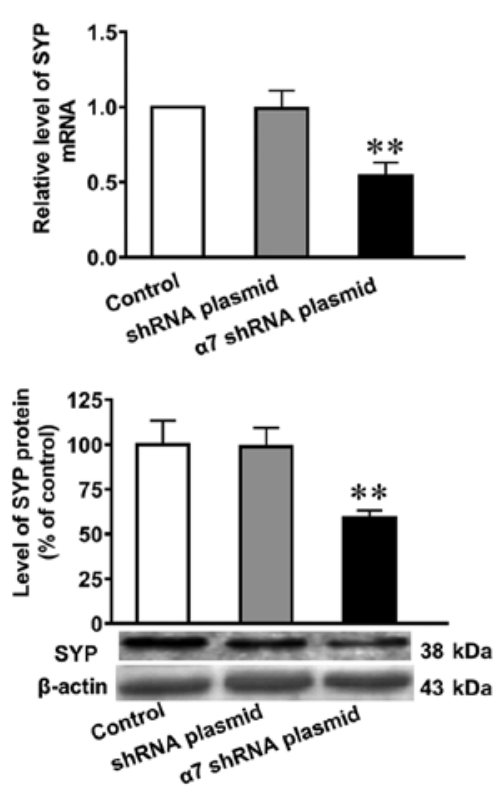

B
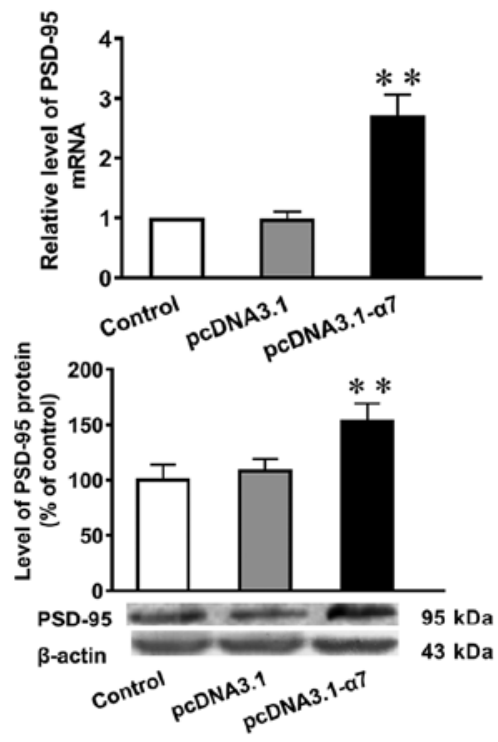

E
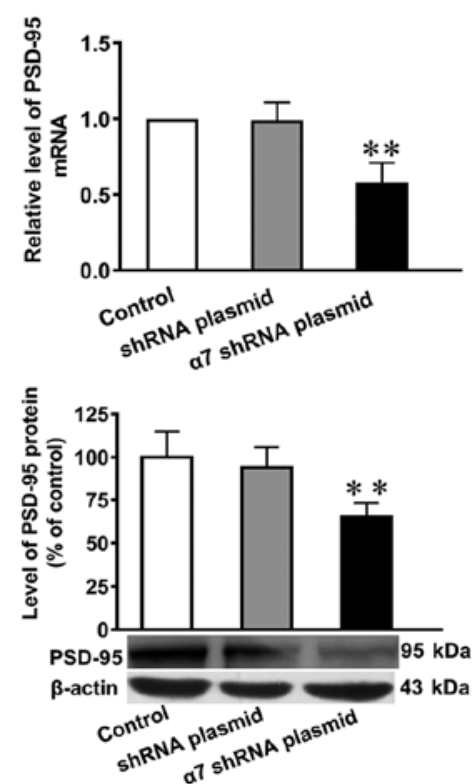

C

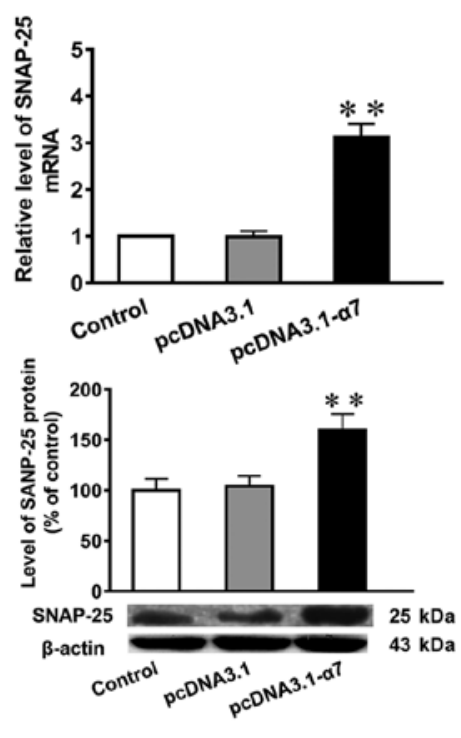

F
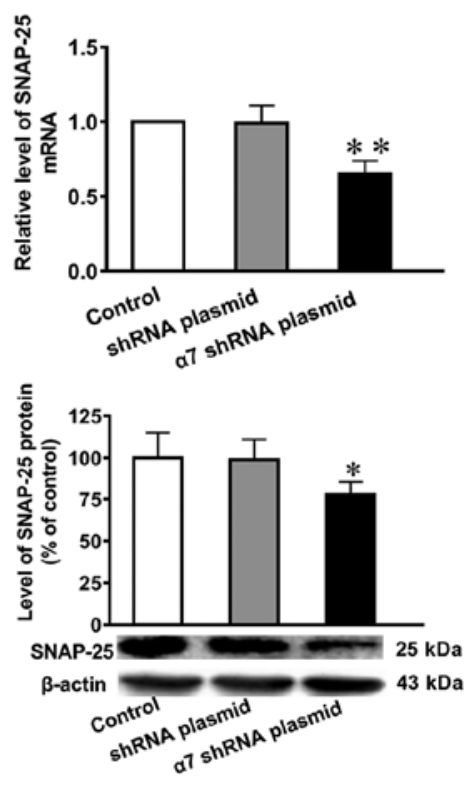

Figure 4. Expression levels of SYP, PSD-95 and SNAP-25 in SH-SY5Y cells overexpressing $\alpha 7 \mathrm{nAChR}$ or with silenced $\alpha 7 \mathrm{nAChR}$ expression. Expression levels of mRNA and protein were determined using reverse transcription-quantitative PCR and western blotting, respectively. mRNA and protein expression levels of (A) SYP, (B) PSD-95 and (C) SNAP-25 after $\alpha 7$ nAChR overexpression. mRNA and protein expression levels of (D) SYP, (E) PSD-95 and (F) SNAP-25 after $\alpha 7$ nAChR silencing. Data are presented as the mean \pm standard deviation $(\mathrm{n}=9)$. ${ }^{*} \mathrm{P}<0.05$ and ${ }^{* * *} \mathrm{P}<0.01$ vs. control. SYP, synaptophysin; PSD-95, postsynaptic density of $95 \mathrm{kDa}$; SNAP-25, synaptosomal-associated protein of $25 \mathrm{kDa} ; \alpha 7 \mathrm{nAChR}$, nicotinic acetylcholine receptor $\alpha 7 \mathrm{kubunit}$; shRNA, short hairpin RNA.

altered expression levels of $\alpha 7 \mathrm{nAChR}$ on the concentration of $\mathrm{ACh}$ and the activity of AChE was investigated in SH-SY5Y cells. The findings indicated that there were no significant differences in either ACh concentration or AChE activity in the treated cells. The possible reason for the emergence of this result is that $\alpha-7 \mathrm{nAChR}$ can increase the release of $\mathrm{ACh}$ and affect the activity of $\mathrm{AChE}$ under short-term conditions; however, under the conditions of the present study, this change was not observed. The present results suggested that changes in the expression levels of $\alpha 7 \mathrm{nAChR}$ in SH-SY5Y cells may not affect $\mathrm{ACh}$ concentrations and $\mathrm{AChE}$ activity, which requires further investigation.
Numerous studies have reported that $\alpha 7 \mathrm{nAChR}$ served an important role in cognitive processes in brains of patients with $\mathrm{AD}$, which may be related to the inhibition of $\mathrm{A} \beta$ toxicity and modulation of synaptic transmission and plasticity (44-46).

The findings of the present study suggested that the expression levels of $A \beta$ in the brains of patients with $A D$ were increased compared with the healthy control group, and the expression levels of $\alpha 7 \mathrm{nAChR}$ in brain sections of patients with AD were decreased. Immunofluorescence double staining identified that the expression levels of $\mathrm{A} \beta$ were decreased in the brain regions exhibiting higher expression levels of $\alpha 7$ $\mathrm{nAChR}$; a negative correlation was found between $\alpha 7 \mathrm{nAChR}$ 
Table II. Concentration of ACh and the activity of AChE in SH-SY5Y cells in which expression of $\alpha 7 \mathrm{nAChR}$ was overexpressed or silenced.

\begin{tabular}{lcc}
\hline Group & ACh concentration $(\mu \mathrm{g} / \mathrm{ml})$ & AChE activity $(\mathrm{U} / \mathrm{ml})$ \\
\hline Control & $25.32 \pm 1.82$ & $0.79 \pm 0.18$ \\
pcDNA 3.1 & $25.75 \pm 2.07$ & $0.85 \pm 0.23$ \\
a7 nAChR-pcDNA 3.1 & $27.72 \pm 4.02$ & $0.71 \pm 0.20$ \\
Control shRNA plasmid B & $26.59 \pm 3.82$ & $0.74 \pm 0.16$ \\
$\alpha 7$ nAChR shRNA plasmid B & $29.97 \pm 2.78$ & $0.82 \pm 0.22$ \\
\hline
\end{tabular}

ACh, acetylcholine; AChE, acetylcholinesterase; $\alpha 7 \mathrm{nAChR}$, nicotinic acetylcholine receptor $\alpha 7$ subunit; shRNA, short hairpin RNA.

A
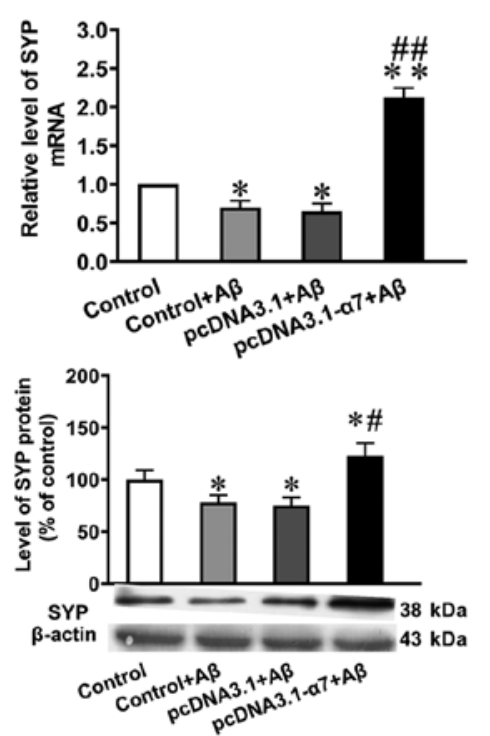

D
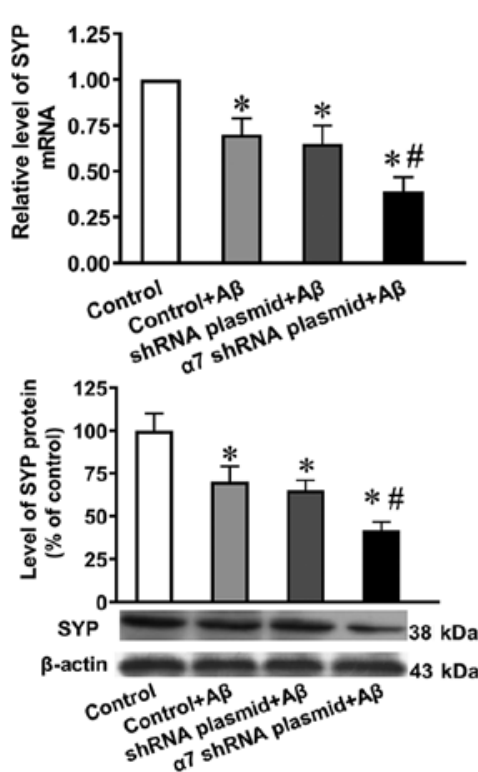

B
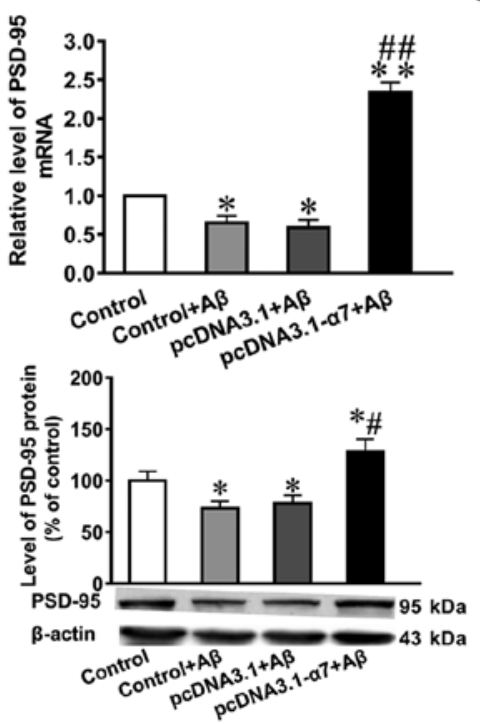

$E$
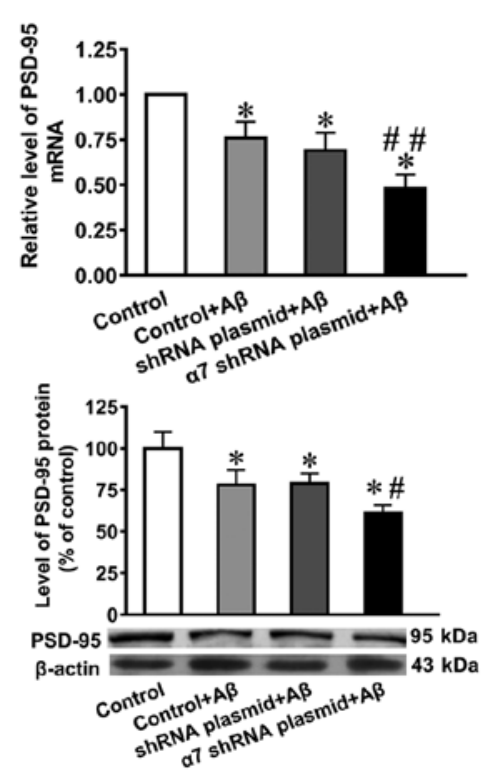

C
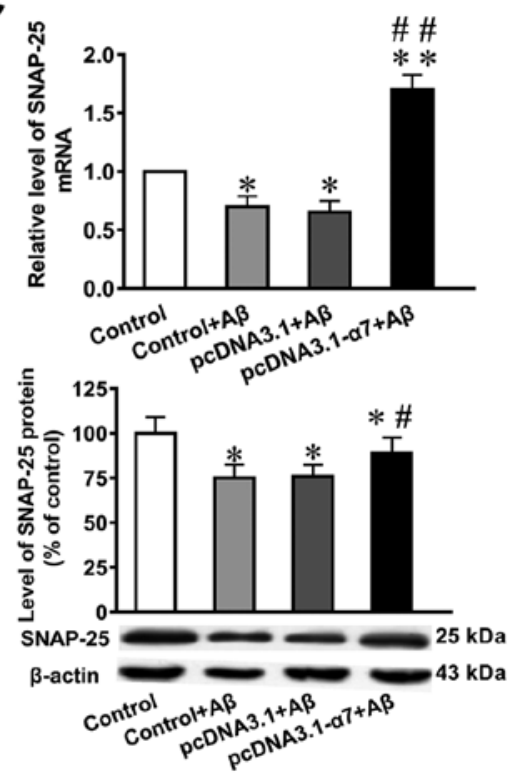

F
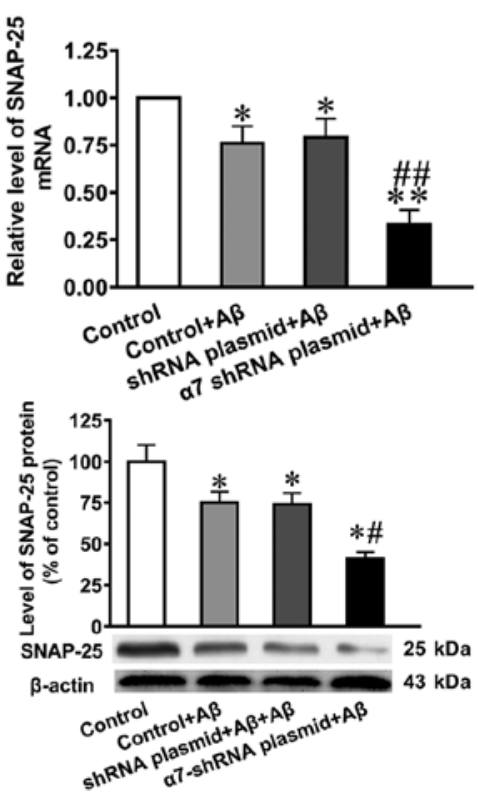

Figure 5. Expression levels of SYP, PSD-95 and SNAP-25 in SH-SY5Y cells following the overexpression of $\alpha 7 \mathrm{nAChR}$ or silencing of $\alpha 7 \mathrm{nAChR}$, and exposure to A $\beta O$. mRNA and protein expression levels of (A) SYP, (B) PSD-95 and (C) SNAP-25 after $\alpha 7 \mathrm{nAChR}$ overexpression. mRNA and protein expression levels of (D) SYP, (E) PSD-95 and (F) SNAP-25 after $\alpha 7 \mathrm{nAChR}$ silencing. The expression levels of mRNA and protein were determined using reverse transcription-quantitative PCR and western blotting, respectively. Data are presented as the mean \pm standard deviation ( $\mathrm{n}=9$ ). ${ }^{*} \mathrm{P}<0.05$ and ${ }^{* *} \mathrm{P}<0.01$ vs. control; ${ }^{\# \#} \mathrm{P}<0.01,{ }^{\#} \mathrm{P}<0.05$ vs. empty plasmid. SYP, synaptophysin; PSD-95, postsynaptic density of $95 \mathrm{kDa}$; SNAP-25, synaptosomal-associated protein of $25 \mathrm{kDa}$; $\alpha 7$ $\mathrm{nAChR}$, nicotinic acetylcholine receptor $\alpha 7$ subunit; $\mathrm{A} \beta \mathrm{O}, \mathrm{A} \beta 1-42$ oligomer; shRNA, short hairpin RNA. 
A
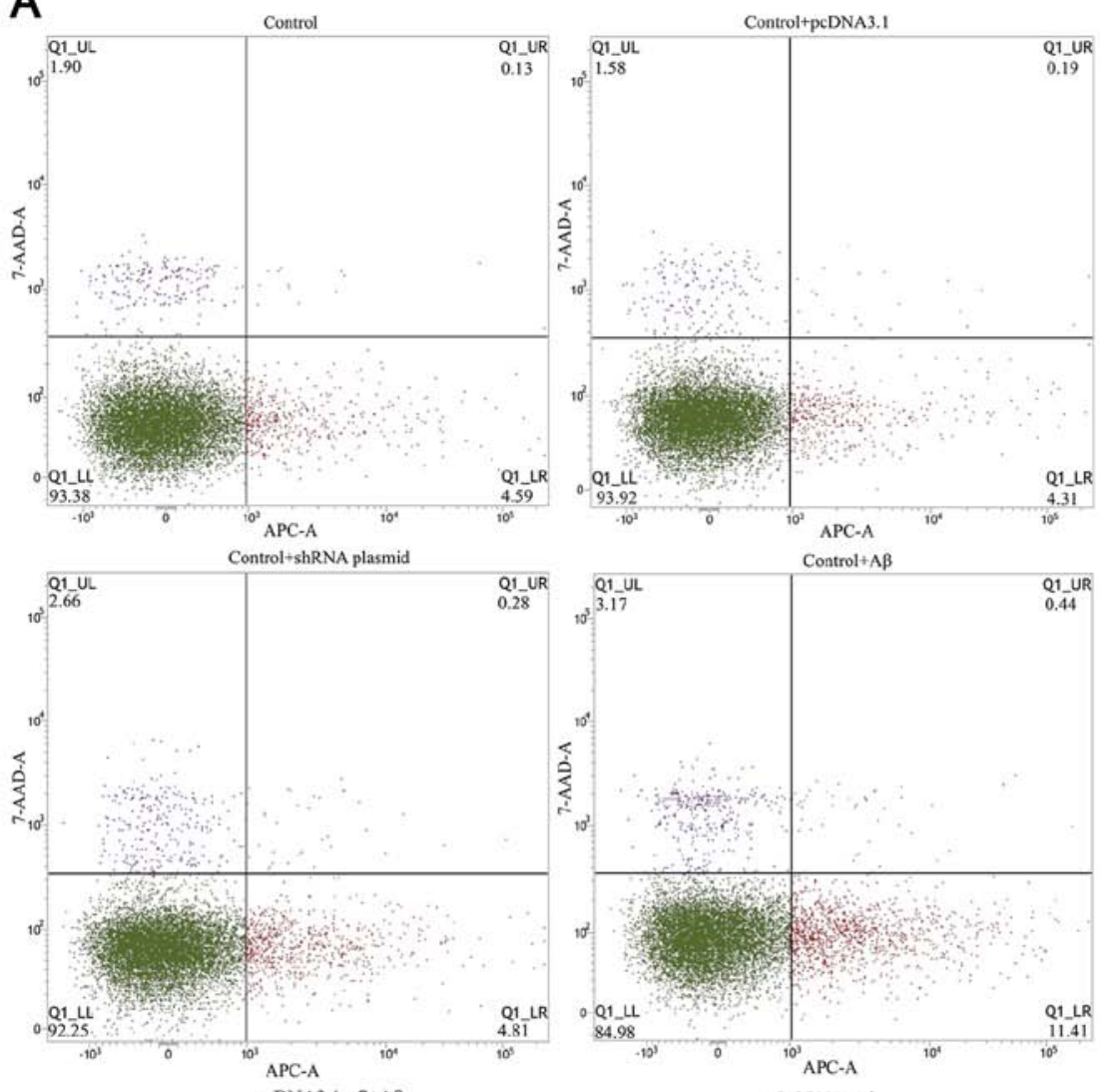

B
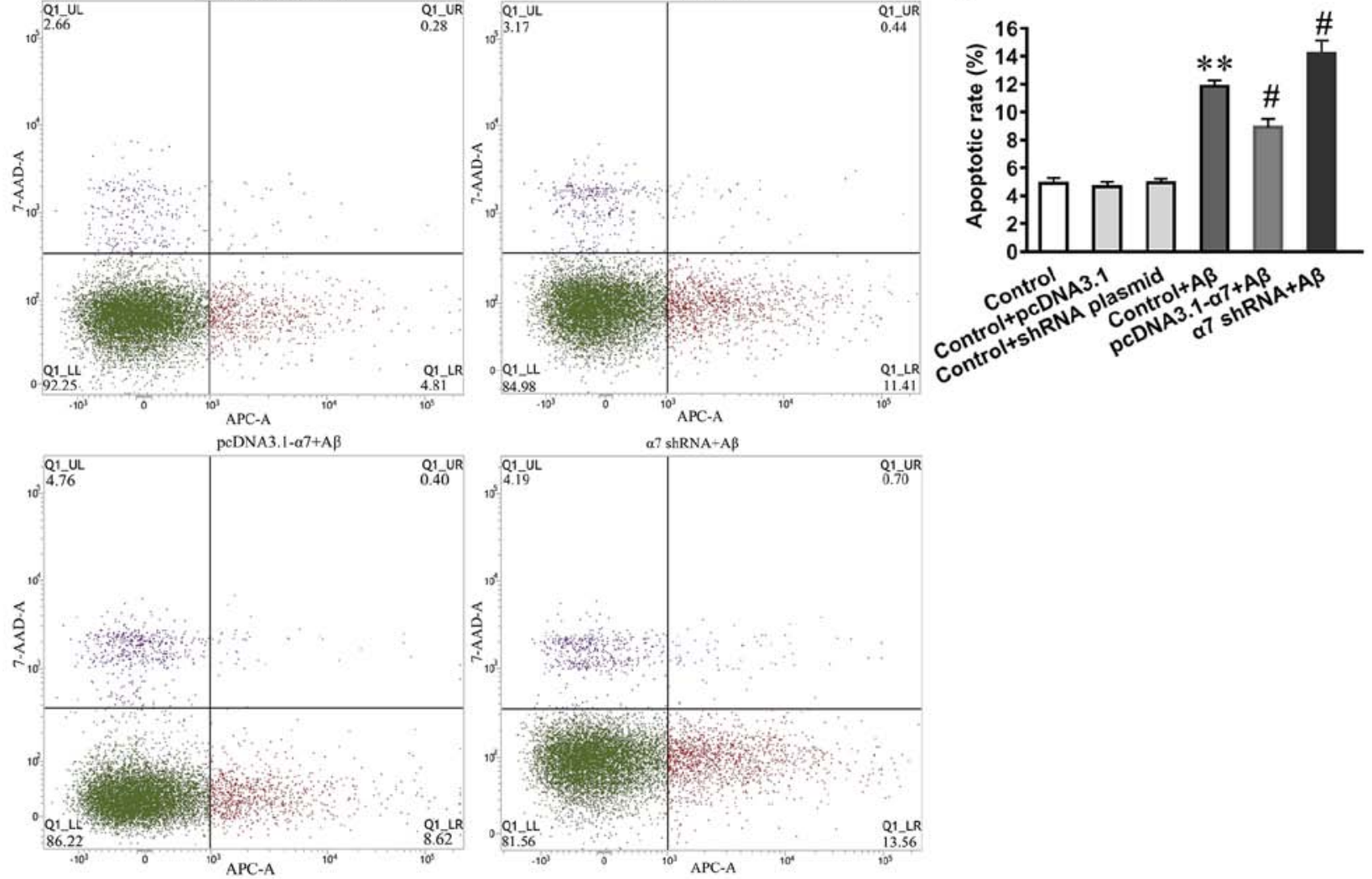

Figure 6. Apoptotic rate of SH-SY5Y cells, which are simultaneously exposed to $\alpha 7 \mathrm{nAChR}$ overexpression or gene silencing and A $\beta$ O. (A) Apoptotic rate was determined using flow cytometry and $(\mathrm{B})$ data are presented as the mean \pm standard deviation $(\mathrm{n}=9)$. ${ }^{* *} \mathrm{P}<0.01 \mathrm{vs}$. control; ${ }^{*} \mathrm{P}<0.05$ vs. control $+\mathrm{A} \beta \mathrm{O}$. $\alpha 7 \mathrm{nAChR}$, nicotinic acetylcholine receptor $\alpha 7$ subunit; $\mathrm{A} \beta \mathrm{O}, \mathrm{A} \beta 1-42$ oligomer; shRNA, short hairpin RNA.

and $\mathrm{A} \beta$ in the temporal lobe, frontal lobe and hippocampus of patients with AD, which suggested that $\alpha 7 \mathrm{nAChR}$ may have a neuroprotective effect in the brains of patients with AD. Subsequently, the neuroprotective effect of $\alpha 7 \mathrm{nAChR}$ in SH-SY5Y was investigated. It was speculated that the correlation may be due to the neuronal loss induced by $\mathrm{A} \beta$ by $\mathrm{A} \beta$ itself. However, due to the lack of human brain tissue specimens, the present study did not perform hematoxylin-eosin staining.

In the present study, mRNA and protein expression levels of SYP, SNAP-25 and PSD-95 were significantly increased in the neuronal cells overexpressing $\alpha 7 \mathrm{nAChR}$, while decreased expression levels were observed following $\alpha 7$ nAChR RNA silencing. These results suggested that $\alpha 7 \mathrm{nAChR}$ may be involved in regulating the expression of these proteins, in addition to other synaptic proteins, which would establish a link to synaptic stabilization and plasticity. It has been revealed that SYP levels in the superior temporal and inferior parietal cortex are $\sim 5 \%$ lower in patients with severe AD compared with individuals with no cognitive impairment (47). Our previous study reported significantly decreased expression levels of SYP protein and mRNA in the brains of patients with AD, mice carrying the amyloid protein precursor $(\mathrm{APP})_{\mathrm{SWE}}$ mutation and rats injected with $A \beta_{1-42}$ (48). Furthermore, the expression levels of PSD-95 and SNAP-25 are decreased in the cerebral cortex of 3xTg-AD mice (49). The findings of the present study also indicated that $\alpha 7 \mathrm{nAChR}$ may provide a link to synaptic stabilization, plasticity and transmission in the nervous system, which may be related to the protective function of this receptor against cognitive decline during the pathogenesis of $\mathrm{AD}$. However, $\alpha 7 \mathrm{nAChR}$ may regulate synaptic plasticity by 
regulating the level of calcium ions, which will be the subject of future studies.

A $\beta$ exerts its synaptotoxicity by suppressing long-term potentiation, impairing synaptic plasticity and inducing neuronal dysfunction (50). The synaptotoxic effect of $A \beta_{42}$ peptides was suggested to be one of the most important aspects of the pathogenic process resulting in AD (51), and significantly reduced expression levels of SYP, PSD-95 and SNAP-25 have been revealed in the brains of mice influenced by $A \beta$ (52-54). Moreover, the present study detected significant reductions in the expression levels of SYP, PSD-95 and SNAP-25 in SH-SY5Y cells exposed to A $\beta O$, which may reflect the synaptotoxic effects induced by $A \beta$.

In the present study, the inhibitory effects of $A \beta$ on the expression levels of SYP, PSD-95 and SNAP-25 were significantly attenuated following the increased expression levels of $\alpha 7 \mathrm{nAChR}$ and potentiated following $\alpha 7 \mathrm{nAChR}$ RNA silencing. These observations indicated that $\alpha 7 \mathrm{nAChR}$ may also prevent the loss of synaptic proteins caused by $A \beta$ in vivo. It has been previously reported that the inhibition of the expression levels of $\alpha 7 \mathrm{nAChR}$ in SH-SY5Y cells by RNA interference increases the toxicity and expression levels of $A \beta$, which subsequently elevates the expression levels of $\beta$-site APP-cleaving enzyme 1 (BACE1) and decreases the expression levels of BACE2 $(38,55)$. In the present study, the expression levels of synaptic proteins were reduced to a greater extent by $\mathrm{A} \beta$ in the presence of $\alpha 7 \mathrm{nAChR}$ silencing, which may be related to the reduced production of $\mathrm{A} \beta$ caused by $\alpha 7 \mathrm{nAChR}$. In addition, it was found that the treatment of SH-SY5Y cells with $\mathrm{A} \beta \mathrm{O}$ significantly increased the apoptotic rate, while the proliferation of the cells was poor (data not shown), which was attenuated by $\alpha 7 \mathrm{nAChR}$ overexpression and potentiated by $\alpha 7 \mathrm{nAChR}$ silencing. These findings suggested that $\alpha 7 \mathrm{nAChR}$ may effectively decrease $\mathrm{A} \beta \mathrm{O}$-induced neuronal apoptosis, which may be connected to the increased expression of synaptic proteins.

In conclusion, the expression levels of $A \beta$ in the brain of patients with AD were significantly increased compared with the healthy control group, whereas the expression levels of $\alpha 7 \mathrm{nAChR}$ in the brain of patients with AD were significantly decreased compared with the healthy control group. Furthermore, it was demonstrated that the expression levels of $\alpha 7 \mathrm{nAChR}$ and $\mathrm{A} \beta$ were negatively correlated with each other in the brain of patients with AD. The mRNA and protein expression levels of SYP, SNAP-25 and PSD-95 were all significantly increased following the overexpression of $\alpha 7 \mathrm{nAChR}$, but were reduced following RNA silencing of this receptor. In un-transfected or negative control cells, the expression levels of these factors and the apoptotic rate were significantly reduced following the exposure to $\mathrm{A} \beta \mathrm{O}$, which was found to be attenuated by $\alpha 7 \mathrm{nAChR}$ overexpression, but potentiated by $\alpha 7 \mathrm{nAChR}$ RNA silencing. Overall, these findings suggested that $\alpha 7 \mathrm{nAChR}$ may serve an important neuroprotective role related to the pathogenesis of $\mathrm{AD}$ and it may be useful for future drug developments in AD.

\section{Acknowledgements}

The authors would like to thank the Netherlands Brain Bank for providing the brain tissue samples.

\section{Funding}

This work was supported by grants from the Chinese National Natural Science Foundation (grant no. 81860207), the Program for Changjiang Scholars and Innovative Research Team in University (grant no. IRT13058), the Guizhou Foundation [grant. nos.(2014)06 and 2014(6008)], The Guizhou Science and Technology Foundation [grant no. (2019)1437] and the Guizhou Province Graduate Education Innovation Program Foundation [grant nos. YJSCXJH(2018)040 and YJSCXJH(2019)070].

\section{Availability of data and materials}

The datasets used and/or analyzed during the present study are available from the corresponding author on reasonable request

\section{Authors' contributions}

XLQ and JMR designed the study, JMR wrote and revised the manuscript. JMR and SLZ analyzed the data and revised the manuscript. SLZ, XLW and ZZG performed the experiments. ZZG helped perform the analysis of the data and provided constructive discussions. All authors read and approved the final manuscript

\section{Ethics approval and consent to participate}

The study was approved by the Ethics Committee of the Affiliated Hospital of Guizhou Medical University. All the brain tissue blocks had been donated voluntarily by the patient or with the consent of the family.

\section{Patient consent for publication}

Not applicable.

\section{Competing interests}

The authors declare that they have no competing interests.

\section{References}

1. Bloom GS: Amyloid- $\beta$ and tau: The trigger and bullet in Alzheimer disease pathogenesis. JAMA Neurol 71: 505-508, 2014.

2. Amemori T, Jendelova P, Ruzicka J, Urdzikova LM and Sykova E: Alzheimer's disease: Mechanism and approach to cell therapy. Int J Mol Sci 16: 26417-26451, 2015.

3. Ferreira ST, Lourenco MV, Oliveira MM and De Felice FG: Soluble amyloid- $\beta$ oligomers as synaptotoxins leading to cognitive impairment in Alzheimer's disease. Front Cell Neurosci 9: 191, 2015.

4. Viola KL and Klein WL: Amyloid $\beta$ oligomers in Alzheimer's disease pathogenesis, treatment, and diagnosis. Acta Neuropathol 129: 183-206, 2015.

5. Lesné SE, Sherman MA, Grant M, Kuskowski M, Schneider JA, Bennett DA and Ashe KH: Brain amyloid- $\beta$ oligomers in ageing and Alzheimer's disease. Brain 136: 1383-1398, 2013.

6. Magi S, Castaldo P, Macrì ML, Maiolino M, Matteucci A, Bastioli G, Gratteri S, Amoroso S and Lariccia V: Intracellular calcium dysregulation: Implications for Alzheimer's disease. BioMed Res Int 2016: 6701324, 2016.

7. Jagust W: Is amyloid- $\beta$ harmful to the brain? Insights from human imaging studies. Brain 139: 23-30, 2016.

8. Overk CR and Masliah E: Pathogenesis of synaptic degeneration in Alzheimer's disease and Lewy body disease. Biochem Pharmacol 88: 508-516, 2014. 
9. Sheng M, Sabatini BL and Südhof TC: Synapses and Alzheimer's disease. Csh Perspect Biol 4: doi.org/10.1101/cshperspect.a005777.

10. Harrill JA, Chen H, Streifel KM, Yang D, Mundy WR and Lein PJ: Ontogeny of biochemical, morphological and functional parameters of synaptogenesis in primary cultures of rat hippocampal and cortical neurons. Mol Brain 8: 10, 2015.

11. García-Morales V, Montero F, González-Forero D, Rodríguez-Bey G, Gómez-Pérez L, Medialdea-Wandossell MJ, Domínguez-Vías G, García-Verdugo JM and Moreno-López B Membrane-derived phospholipids control synaptic neurotransmission and plasticity. PLoS Biol 13: e1002153, 2015.

12. Wang DB, Kinoshita Y, Kinoshita C, Uo T, Sopher BL, Cudaback E, Keene CD, Bilousova T, Gylys K, Case A, et al: Loss of endophilin-B1 exacerbates Alzheimer's disease pathology. Brain 138: 2005-2019, 2015.

13. Marcello E, Epis R, Saraceno C and Di Luca M: Synaptic dysfunction in Alzheimer's disease. Adv Exp Med Biol 970: 573-601, 2012.

14. Wang DB, Kinoshita Y, Kinoshita C, Uo T, Sopher BL, Cudaback E, Keene CD, Bilousova T, Gylys K, Case A, et al: Loss of endophilin-B1 exacerbates Alzheimer's disease pathology. Brain 138: 2005-2019, 2015.

15. Sivanesan S, Tan A and Rajadas J: Pathogenesis of Abeta oligomers in synaptic failure. Curr Alzheimer Res 10: 316-323, 2013.

16. Antonucci F, Corradini I, Fossati G, Tomasoni R, Menna E and Matteoli M: SNAP-25, a known presynaptic protein with emerging postsynaptic functions. Front Synaptic Neurosci 8: 7 , 2016.

17. Wang J, Yuan J and Pang J, Ma J, Han B, Geng Y, Shen L, Wang H, Ma Q, Wang Y and Wang M: Effects of chronic stress on cognition in male SAMP8 mice. Cell Physiol Biochem 39: 1078-1086, 2016.

18. Xi YD, Zhang DD, Ding J, Yu HL, Yuan LH, Ma WW, Han J and Xiao R: Genistein inhibits A 325 -35-induced synaptic toxicity and regulates CaMKII/CREB pathway in SH-SY5Y cells. Cell Mol Neurobiol 36: 1151-1159, 2016.

19. Ito S, Ménard M, Atkinson T, Brown L, Whitfield J and Chakravarthy B: Relative expression of the p75 neurotrophin receptor, tyrosine receptor kinase $\mathrm{A}$, and insulin receptor in SH-SY5Y neuroblastoma cells and hippocampi from Alzheimer's disease patients. Neurochem Int 101: 22-29, 2016.

20. Gray NE, Zweig JA, Kawamoto C, Quinn JF and Copenhaver PF: STX, a novel membrane estrogen receptor ligand, protects against amyloid- $\beta$ toxicity. J Alzheimers Dis 51: 391-403, 2016.

21. Ferreira-Vieira TH, Guimaraes IM, Silva FR and Ribeiro FM Alzheimer's disease: Targeting the cholinergic system. Curr Neuropharmacol 14: 101-115, 2016.

22. Park D, Choi EK, Cho TH, Joo SS and Kim YB: Human neural stem cells encoding ChAT gene restore cognitive function via acetylcholine synthesis, $\mathrm{A} \beta$ elimination, and neuroregeneration in APPswe/PS1dE9 mice. Int J Mol Sci 21: 21, 2020.

23. Badin AS, Eraifej J and Greenfield S: High-resolution spatio-temporal bioactivity of a novel peptide revealed by optical imaging in rat orbitofrontal cortex in vitro: Possible implications for neurodegenerative diseases. Neuropharmacology 73: 10-18, 2013.

24. Galimberti D and Scarpini E: Old and new acetylcholinesterase inhibitors for Alzheimer's disease. Expert Opin Investig Drugs 25: 1181-1187, 2016

25. Fukunaga $\mathrm{K}$ and Yabuki Y: SAK3-induced neuroprotection is mediated by nicotinic acetylcholine receptors. In: Nicotinic Acetylcholine Receptor Signaling in Neuroprotection. Akaike A, Shimohama S and Yoshimi Misu Y (eds). Springer, Berlin, pp159-171, 2018.

26. Hernandez CM, Kayed R, Zheng H, Sweatt JD and Dineley KT: Loss of alpha7 nicotinic receptors enhances beta-amyloid oligomer accumulation, exacerbating early-stage cognitive decline and septohippocampal pathology in a mouse model of Alzheimer's disease. J Neurosci 30: 2442-2453, 2010

27. Gil SM and Metherate R: Enhanced sensory-cognitive processing by activation of nicotinic acetylcholine receptors. Nicotine Tob Res 21: 377-382, 2019.

28. Gu Z and Yakel JL: Timing-dependent septal cholinergic induction of dynamic hippocampal synaptic plasticity. Neuron 71: $155-165,2011$.

29. Lozada AF, Wang X, Gounko NV, Massey KA, Duan J, Liu Z and Berg DK: Glutamatergic synapse formation is promoted by $\alpha 7$-containing nicotinic acetylcholine receptors. J Neurosci 32: 7651-7661, 2012
30. Yue Y, Liu R, Cheng W, Hu Y, Li J, Pan X, Peng J and Zhang P: GTS-21 attenuates lipopolysaccharide-induced inflammatory cytokine production in vitro by modulating the Akt and NF- $x \mathrm{~B}$ signaling pathway through the $\alpha 7$ nicotinic acetylcholine receptor. Int Immunopharmacol 29: 504-512, 2015.

31. Tyagi E, Agrawal R, Nath C and Shukla R: Inhibitory role of cholinergic system mediated via alpha7 nicotinic acetylcholine receptor in LPS-induced neuro-inflammation. Innate Immun 16 3-13, 2010.

32. Liao Y, Qi XL, Cao Y, Yu WF, Ravid R, Winblad B, Pei JJ and Guan ZZ: Elevations in the levels of NF- $x \mathrm{~B}$ and inflammatory chemotactic factors in the brains with Alzheimer's disease - One mechanism may involve $\alpha 3$ nicotinic acetylcholine receptor. Curr Alzheimer Res 13: 1290-1301, 2016.

33. Domínguez-Álvaro M, Montero-Crespo M, Blazquez-Llorca L, InsaustiR,DeFelipe Jand Alonso-NanclaresL:Three-dimensional analysis of synapses in the transentorhinal cortex of Alzheimer's disease patients. Acta Neuropathol Commun 6: 20, 2018.

34. Bauwens M, Mottaghy FM and Bucerius J: PET imaging of the human nicotinic cholinergic pathway in atherosclerosis. Curr Cardiol Rep 17: 67, 2015.

35. Dubois B, Feldman HH, Jacova C, Dekosky ST, Barberger-Gateau P, Cummings J, Delacourte A, Galasko D, Gauthier S, Jicha G, et al: Research criteria for the diagnosis of Alzheimer's disease: Revising the NINCDS-ADRDA criteria. Lancet Neurol 6: 734-746, 2007.

36. McKhann G, Drachman D, Folstein M, Katzman R, Price D and Stadlan EM: Clinical diagnosis of Alzheimer's disease: Report of the NINCDS-ADRDA work group under the auspices of Department of Health and Human Services Task Force on Alzheimer's disease. Neurology 34: 939-944, 1984.

37. Reisberg B, Ferris SH, de Leon MJ and Crook T: The Global Deterioration Scale for assessment of primary degenerative dementia. Am J Psychiatry 139: 1136-1139, 1982.

38. Wang XL, Deng YX, Gao YM, Dong YT, Wang F, Guan ZZ, Wei H and Qi XL: Activation of $\alpha 7 \mathrm{nAChR}$ by PNU-282987 improves synaptic and cognitive functions through restoring the expression of synaptic-associated proteins and the CaM-CaMKII-CREB signaling pathway. Aging (Albany NY) 12: 543-570, 2020

39. Livak KJ and Schmittgen TD: Analysis of relative gene expression data using real-time quantitative PCR and the 2(-Delta Delta C(T)) Method. Methods 25: 402-408, 2001.

40. Dunant $Y$ and Gisiger V: Ultrafast and slow cholinergic transmission. Different involvement of acetylcholinesterase molecular forms. Molecules 22: 1300, 2017.

41. Dani JA and Bertrand D: Nicotinic acetylcholine receptors and nicotinic cholinergic mechanisms of the central nervous system. Annu Rev Pharmacol Toxicol 47: 699-729, 2007.

42. Albiñana E, Luengo JG, Baraibar AM, Muñoz MD, Gandía L, Solís JM and Hernández-Guijo JM: Choline induces opposite changes in pyramidal neuron excitability and synaptic transmission through a nicotinic receptor-independent process in hippocampal slices. Pflugers Arch 469: 779-795, 2017.

43. Huang M, Felix AR, Kwon S, Lowe D, Wallace T, Santarelli L and Meltzer HY: The alpha-7 nicotinic receptor partial agonist/5-HT3 antagonist RG3487 enhances cortical and hippocampal dopamine and acetylcholine release. Psychopharmacology (Berl) 231: 2199-2210, 2014

44. Stoiljkovic M, Kelley C, Nagy D, Hurst R and Hajós M: Activation of $\alpha 7$ nicotinic acetylcholine receptors facilitates long-term potentiation at the hippocampal-prefrontal cortex synapses in vivo. Eur Neuropsychopharmacol 26: 2018-2023, 2016.

45. Lagostena L, Trocme-Thibierge C, Morain P and Cherubini E: The partial alpha7 nicotine acetylcholine receptor agonist $S$ 24795 enhances long-term potentiation at CA3-CA1 synapses in the adult mouse hippocampus. Neuropharmacology 54: 676-685, 2008.

46. Inestrosa NC, Godoy JA, Vargas JY, Arrazola MS, Rios JA, Carvajal FJ, Serrano FG and Farias GG: Nicotine prevents synaptic impairment induced by amyloid- $\beta$ oligomers through $\alpha 7$-nicotinic acetylcholine receptor activation. Neuromolecular Med 15: 549-569, 2013.

47. Counts SE, Nadeem M, Lad SP, Wuu J and Mufson EJ: Differential expression of synaptic proteins in the frontal and temporal cortex of elderly subjects with mild cognitive impairment. J Neuropathol Exp Neurol 65: 592-601, 2006.

48. Cao Y, Xiao Y, Ravid R and Guan ZZ: Changed clathrin regulatory proteins in the brains of Alzheimer's disease patients and animal models. J Alzheimers Dis 22: 329-342, 2010. 
49. Carvalho C, Santos MS, Oliveira CR and Moreira PI: Alzheimer's disease and type 2 diabetes-related alterations in brain mitochondria, autophagy and synaptic markers. Biochim Biophys Acta 1852: 1665-1675, 2015.

50. Ferreira ST and Klein WL: The A $\beta$ oligomer hypothesis for synapse failure and memory loss in Alzheimer's disease. Neurobiol Learn Mem 96: 529-543, 2011.

51. Tu S, Okamoto S, Lipton SA and Xu H: Oligomeric A $\beta$-induced synaptic dysfunction in Alzheimer's disease. Mol Neurodegener 9: $48,2014$.

52. Wang S, Yu L, Yang H, Li C, Hui Z, Xu Y and Zhu X: Oridonin attenuates synaptic loss and cognitive deficits in an $A \beta 1$-42-induced mouse model of Alzheimer's disease. PLoS One 11: e0151397, 2016.

53. Liu SJ, Yang C, Zhang Y, Su RY, Chen JL, Jiao MM, Chen HF, Zheng N, Luo S, Chen YB, et al: Neuroprotective effect of $\beta$-asarone against Alzheimer's disease: Regulation of synaptic plasticity by increased expression of SYP and GluR1. Drug Des Devel Ther 10: 1461-1469, 2016.
54. Chauhan NB, Lichtor T and Siegel GJ: Aging potentiates Abeta-induced depletion of SNAP-25 in mouse hippocampus. Brain Res 982: 219-227, 2003.

55. Qi XL, Nordberg A, Xiu J and Guan ZZ: The consequences of reducing expression of the alpha7 nicotinic receptor by RNA interference and of stimulating its activity with an alpha7 agonist in SH-SY5Y cells indicate that this receptor plays a neuroprotective role in connection with the pathogenesis of Alzheimer's disease. Neurochem Int 51: 377-383, 2007.

This work is licensed under a Creative Commons Attribution-NonCommercial-NoDerivatives 4.0 International (CC BY-NC-ND 4.0) License. 